\title{
Transacting Business through/for Others in Early Colonial Western India: The Text, Context, and Meaning of a Mukhtār-nāma of 1821
}

\author{
Ghulam A. Nadri \\ Georgia State University, Atlanta, Georgia, USA \\ gnadri@gsu.edu
}

\begin{abstract}
In the Persianate world, a mukhtār-nāma (deed of representation or a power of attorney) was a legal instrument that enabled people to transact business through a representative or agent (mukhtār or wakìl). This is a study of one such document written in Surat in 1821. It analyses the document for its socio-cultural, legal, and commercial significance as well as to explore the transition in the adjudication of commercial disputes and civil cases from Mughal to East India Company courts. It shows that there was a strong tradition of documenting business transactions in early modern South Asia and that such practices have continued into the colonial and postcolonial periods.
\end{abstract}

\section{Keywords}

Surat - power of attorney - Parsi - merchants - qazi

\section{Introduction}

In early modern South Asia and elsewhere in the Persianate world, there were mechanisms in place which enabled people to make formal and informal commercial and non-commercial transactions through a representative (wakil). ${ }^{1}$ Merchants, in particular, benefited from this institutional provision because

1 The Persianate world refers to those parts of Asia where Persian language or Persianized forms of culture and state institutions had taken deep roots. Since at least the early 13 th century, South Asia was a part of a larger world in which common cultural and political vocabularies 
it enabled them to appoint a legal representative to transact business on their behalf at ports and places where they could not be physically present. In many cases, such a transfer of authority by one person to another was made through a written deed of representation or a power of attorney. In the early modern and colonial Persianate world, a deed of representation or a power of attorney known as wakāla-nāma or mukhtār-nāma was prepared and preserved as a legal document that could be used in a court of law. This and many other forms of documented transactions, such as correspondence between merchants and their distant family members, partners, agents, and brokers, as well as petitions ('arżdāsht), deed of mortgage (rahn or girwwi), and so on, underpinned social and commercial networks in early modern and colonial India. It was not until quite recently, however, that some scholars began scrutinizing the surviving Arabic and Persian documents, including deeds of representation, to address the issues regarding forms and methods of commercial and cultural exchange and communication across spaces, transformation of Islamic law during the colonial period, and the role and positioning of scribes and local religious and judicial authorities in the consolidation and expansion of the colonial state's legal jurisdiction over its colonial subjects. ${ }^{2}$ Through an in-depth analysis of a mukhtār-nāma issued in Surat in 1821, this paper aims to examine how business transactions were documented, what was their legal status, and how people used this mechanism to resolve disputes in a court of law under the English East India Company's colonial rule. This paper also explores the continued relevance of Muslim jurists and the offices of the mufti and qazi (judge) in the colonial judicial system and for the local people in the early nineteenth century. The deed of representation is an example of remarkable historical continuity of a precolonial institution during the colonial period and in postcolonial India as well.

\section{The Historiographical Context}

For a long time, such documents in Persian and Arabic languages have eluded the attention of economic and trade historians, who have been more interested in merchants and flow of trade than in the mechanisms of doing

could be found, which were generally expressed in Persian. For more details, see the introduction of this issue.

2 G.D.S. Sood, India and the Islamic Heartlands: An Eighteenth-Century World of Circulation and Exchange (Cambridge: Cambridge University Press, 2016); E. Lhost, "Writing Law at the Edge of Empire: Evidence from the Qazis of Bharuch (1799-1864)." Itinerario: Journal of Imperial and Global History (hereafter Itinerario) 42/2 (2018): 256-78. 
business and the networks of inter-personal communication which made commercial transactions possible. ${ }^{3}$ Cultural historians took notice of the production of a rich literature in Persian and other languages and wrote about it. Their focus, however, was more on the socio-cultural world of the scribes and on their role in and contribution to state and governance and less on the various forms of knowledge that they produced. ${ }^{4}$ Our understanding of commercial transactions in early modern and colonial South Asia is mainly based on written records of the European East India companies and diaries or memoirs of European merchants, travellers, and adventurers. The dependence on European archives has led to a general impression that transactions of any sort, particularly commercial transactions, in precolonial India were either not recorded or if penned down, the records did not survive or are not accessible to us. Recording commercial transactions on paper and preserving these records for later use constitutes a form of knowledge. This knowledge was not lacking in early modern South Asia, but much of it was lost for lack of a culture of preserving it for posterity. As K.N. Chaudhuri writes, "Merchants and business organisations rarely preserve their records for the benefit of posterity. Once the practical reason for record-keeping is removed, commercial documents are either destroyed or deposited with law courts or religious foundations, according to the social usage of the time. To family inheritors, even when they were engaged in trade, the business papers of another generation made little sense." ${ }^{5}$ Records were lost also because they were not given due recognition in the historiography in colonial India. The mid-eighteenth-century British

3 Beyond the general recognition that merchants had their agents and representatives at distant inland and overseas trading centers to transact business on their behalf, there is hardly any in-depth study of everyday relationship among merchants and their partners and agents in early modern and colonial India. I. Habib, "Merchant Communities in Precolonial India." In The Rise of Merchant Empires: Long-Distance Trade in the Early Modern World, 13501750, ed. J.D. Tracy (Cambridge: Cambridge University Press, 1990): 371-99; K.N. Chaudhuri, "Reflections on the Organizing Principles of Premodern Trade." In The Political Economy of Merchant Empires: State Power and World Trade, 1350-1750, ed. J.D. Tracy (Cambridge: Cambridge University Press, 1991): 421-42. Same is the case in an otherwise influential work on eighteenth-century Basra. T.A.J. Abdullah, Merchants, Mamluks, and Murder: The Political Economy of Trade in Eighteenth-Century Basra (New York: SUNY Press, 2001): 89.

4 M. Alam and S. Subrahmanyam, "Witnesses and Agents of Empire: Eighteenth-Century Historiography and the World of the Mughal Munshī." Journal of the Economic and Social History of the Orient 53/1-2 (2010): 393-423; K. Chatterjee, "Scribal Elites in Sultanate and Mughal Bengal." The Indian Economic and Social History Review 47/2 (2010): 445-72; R. Kinra, "Master and Munshi: A Brahman Secretary's Guide to Mughal Governance." The Indian Economic and Social History Review 47/2 (2010): 527-61.

5 K.N. Chaudhuri, Trade and Civilisation in the Indian Ocean: An Economic History from the Rise of Islam to 1750 (Cambridge: Cambridge University Press, 1985): 204. 
colonial takeover of India and the subsequent discourse on modernity, which considers the latter phenomenon as a peculiarly European development emanating from the European enlightenment, had a major impact on the generation of knowledge in colonial South Asia about its precolonial past. Sheldon Pollock has rightly pointed out that the local forms of knowledge, as expressed in Sanskrit, Persian, Urdu, or other indigenous languages, were overlooked in the colonial period. ${ }^{6}$ Or as Farhat Hasan puts it, "Knowledge of the medieval world becomes useless for the better cognition of the modern period." The result is that other than some selected passages from certain local histories translated and published by colonial/orientalist authors, there was hardly any systematic attempt in the colonial period to study the corpus of knowledge produced in these languages. ${ }^{8}$ In postcolonial South Asia, indigenous sources were indeed used in a major way in writing political and social history. When studying the economic history of South Asia, however, scholars have generally continued to regard the extant indigenous sources as inadequate, and to rely exclusively on European sources instead.

There have been exceptions to this state of affairs. Some scholars have made use of indigenous source to write the agrarian and economic history of the region. ${ }^{9}$ In this historiography, however, the dominant framework was the state and its fiscal policies. Indigenous sources have not been adequately used in writing the history of maritime trade, merchant communities, or of port cities where economic and commercial transactions took place on a large scale. ${ }^{10}$ Moreover, as the interest and expertise in reading primary sources (especially cursive) in Persian, Marathi, Gujarati, Sanskrit, and other indigenous languages

$6 \quad$ S. Pollock, ed., Forms of Knowledge in Early Modern Asia: Explorations in the Intellectual History of India and Tibet, 1500-1800 (Delhi: Manohar, 2011): 5-6.

$7 \quad$ F. Hasan, "Towards a Theory of Social Communication in Pre-Colonial India." Proceedings of the Indian History Congress 63 (2002): 396.

8 H.M. Elliot and J. Dowson, ed., History of India as Told by Its Own Historians: the Muhammadan Period, 8 vols. (London: 1867-1877). For a glimpse into the world of Persian manuscripts written, circulated, collected, and read by emperors, nobles, scholars, and others in precolonial India, see I. Habib, "Persian Book Writing and Book Use in Pre-Printing Age." Proceedings of the Indian History Congress 66 (2005-2006): 514-37.

9 I. Habib, The Agrarian System of Mughal India, 1556-1707 (New Delhi: Cambridge University Press, revised edition, 1999); S.P. Gupta, The Agrarian System of Eastern Rajasthan, c. 16501750 (Delhi: Manohar, 1986).

10 Ashin Das Gupta raised this concern when he wrote "we do not write history in terms of anything as elusive as coastal India for the simple reason that all our history writing has so far been dominated by high politics." A.D. Gupta, "Some Problems of Reconstructing the History of India's West Coast from European Sources." In The World of the Indian Ocean Merchant, 1500-180o: Collected Essays of Ashin Das Gupta, comp. by U. Das Gupta (New Delhi: Oxford University Press, 2001): 253. 
gradually declined, an almost total dependence on European sources became inevitable. ${ }^{11}$ Economic histories, consequently, have been written primarily based on European sources. This is not because there are no indigenous written records but because they are scattered in libraries, archives, museums, and personal collections around the world and, in many cases, they are not properly catalogued and accessible to scholars. As some recent studies have indeed demonstrated, there are local sources in indigenous languages which contain useful information on modes and mechanisms of commercial transaction in the Indian Ocean world in the early modern and colonial periods. ${ }^{12}$ One such collection of Persian documents preserved in the First Dastoor Meherjirana Library, Navsari, contains records of commercial transactions including petition ('arżdāsht), deed of mortgage ( rahn or girwī), agricultural loan (taqāwī), court ruling (faisla-i 'adāla), and numerous documents on land grants and land-related disputes. ${ }^{13}$ The deed of representation or mukhtār-nāma under discussion in the present paper is from this same collection.

\section{Mukhtār-nāma (Arabic: wakāla) in Islamic Law}

The concept of representation or agency (mukhtäriya or wakäla) is central to all forms of commercial contracts and the basis of all contractual partnerships under Islamic law. ${ }^{14}$ Like the partnership, the practical mechanism of agency

11 Even for those who can read such documents, deciphering the text and interpreting it are challenging. Regarding this problem, Irfan Habib writes "as in all cursive scripts, particular forms have developed in shikasta of combination of consonants and other letters of which there can be equally valid alternative readings, and one has to decide from the context which reading is to be adopted." Habib, "Persian Book Writing": 521-2.

12 F.A. Bishara, A Sea of Debt: Law and Economic Life in the Western Indian Ocean, 1780-1950 (Cambridge: Cambridge University Press, 2017); Sood, India and the Islamic Heartlands.

13 The First Dastoor Meherjirana Library (hereafter DML) in Navsari has preserved a large collection of Persian and Pahlavi manuscripts and four bound volumes of miscellaneous Persian (some bilingual Persian and Gujarati) documents mostly from Surat. The documents in this collection include those related with the madad-i ma'ass grants by the Mughals to the Parsi Kaiqobad family of Navsari, disputes over possession of land, and business and property transactions. The library, it seems, acquired these documents from local Parsi families, whose members possessed and transmitted them from one generation to another. The survival of these documents reveals that there was a strong tradition of documenting all kinds of transactions in early modern and colonial India and that the families did not destroy the documents even after they were of no practical use.

14 The Encyclopaedia of Islam, New Edition, vol. 11 (Leiden: Brill, 2002): 57-8; M.R. Ab. Aziz, Islamic Commercial Law (Figh Muamalat): Theory and Application of Selected Contracts (Malaysia: Universiti Sains Islam Malaysia, 2016): 13, 19-23. For many different types of 
is also pre-Islamic and has enabled merchants and people of other professions in all societies to authorise or depute another person to carry out specified tasks. Muslim jurists authorised the conferral of agency as a valid contract and a legitimate means of transacting commercial and legal businesses. Various forms of general and particular contracts of representation were, thus, recognised as legal by the Hanafi and other schools of Islamic jurisprudence. ${ }^{15}$ In the general contract, a merchant authorised his agent (wakil) to carry out transactions on his behalf, but the actual transaction was not specified. In such cases, the agent had a broad mandate and the obligation to carry out commercial transaction judiciously so that both parties benefit from it. In the particular contract, by contrast, the nature of the transaction to be carried out by the agent was specified. In such cases, actual responsibilities were specified in the contract and the agent was authorised to carry out that particular transaction. ${ }^{16}$ Merchants in the early modern Persianate world had recourse to both types of contracts. In carrying out his responsibilities, the agent had a degree of freedom in the manner that he thought was the best and most appropriate under any given circumstances. In Mughal and colonial India, where an overwhelming majority of the population was non-Muslim and did not follow the Islamic law, a representation or agency contract was a purely commercial arrangement between a principal merchant and his agent or representative. Non-Muslim merchants, such as the Parsis, Armenians, Banias, and the Portuguese in Goa, availed themselves of this agency or representation and the format of the deeds in their cases was remarkably similar. ${ }^{17}$ Those entering into such contracts were seemingly unconcerned whether the terms of the contract conformed to the provisions of the Islamic law as interpreted by the jurists of the Hanafi or other schools of Islamic jurisprudence. Muslim jurists in India, who in some cases were the people who ratified the contract, generally did so because the Hanafi school accommodated almost every kind of mutually agreed commercial contract between the principal and his agent. As we will see below, the particular mukhtār-nāma discussed below, was issued by a Parsi inhabitant of

commercial partnerships in Islam, see A.L. Udovitch, Partnership and Profit in Medieval Islam (New Jersey: Princeton University Press, 1970).

15 For a detailed discussion of various types of agency contract and the terms used for those contracts, see M.Y. Saleem, Islamic Commercial Law (Singapore: John Wiley \& Sons, 2013), 68-76.

16 Aziz, Islamic Commercial Law: 19-23.

17 Sood, India and the Islamic Heartlands: 224-9. A striking resemblance between the mukhtār-nāma issued in Surat and Shah Kawthar's power of attorney issued in 1747 in Najaf was the receipt that the agents in both cases were asked to issue upon receiving money from the defendants. 
Surat (most likely a merchant) authorising another Parsi in the presence of two other Parsis to represent him in the court cases against some Parsi and Bania inhabitants of Surat, and was ratified by a Muslim jurist (mufti) of the city.18 The aforesaid mukhtār-nāma is written in Persian in the shikasta-nastālīq style and has names of the principal, Rustamji son of Nausherwanji, and two witnesses, Ratanji son of Hormazji and Darabji son of Nauroji, written in Gujarati. Physical appearances of the two witnesses, Ratanji and Darabji, are also described on the margins of the document in Persian. The contract was ratified by the interpreter of the Islamic law (mufti), Nizamuddin, whose official seal is affixed on the top right of the document. ${ }^{19}$ The contract was signed on 7 July 1821 and, as per the attestation by Abu Turab, sar-rishtedār of the court, a hand copy of the original was submitted to the court on 26 July 1821. Interestingly, the copier of this document also hand copied the seal of the mufti. What follows below is an English translation and an analysis of the text and contents of this mukhtār-nāma.
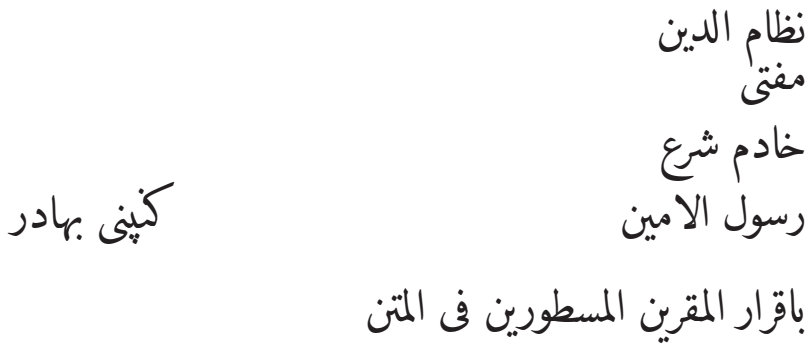

18 DML, Navsari, U 45, part IV, doc. no. 238. A hand copy of this document is also included in this collection (U 45, part IV, doc. no. 243). Judicial authorities and courts under the East India Company's rule in India accepted such contracts drafted in Persian, signed by the parties and witnesses, and ratified by the local Muslim authorities as valid legal documents. Documents without any formal endorsement by the local authorities or witnesses were also valid in the courts of law throughout the British Empire.

19 A mufti was a scholar of Islamic jurisprudence and was a member of the court headed by a qazi. He advised the latter, who alone could give judgement, and gave his legal opinion on cases brought before the court. For details on the office and role of the mufti, see M.B. Ahmad, The Administration of Justice in Medieval India: a Study in Outline of the Judicial System under the Sultans and the Badshahs of Delhi Based mainly upon Cases Decided by Medieval Courts in India between 1206-1750 A.D. (Allahabad:The Allahabad Law Journal Press, 1941). 


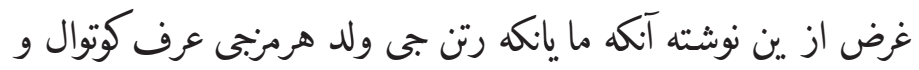

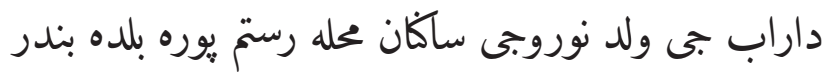

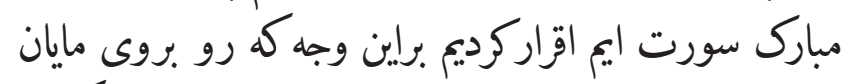

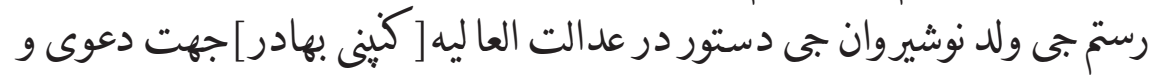

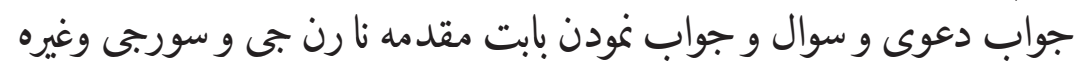

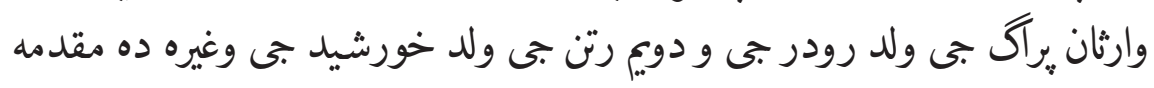

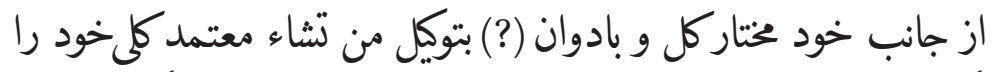

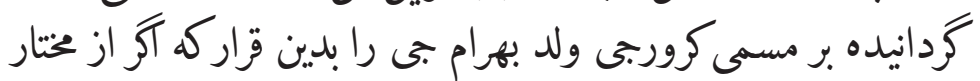

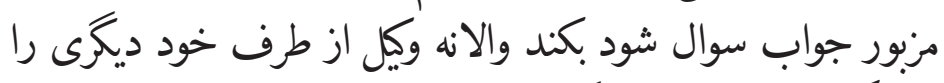

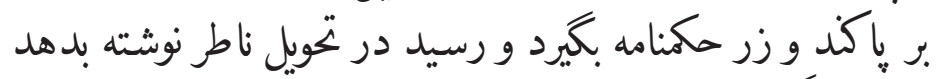

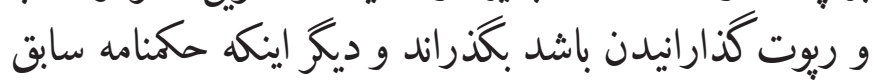

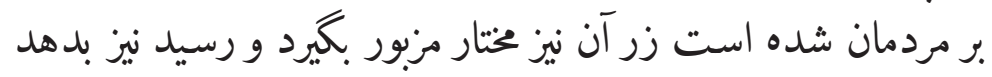

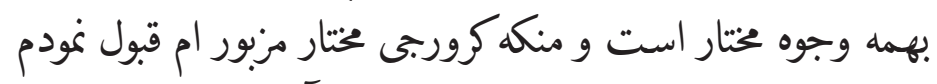

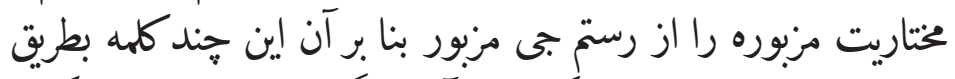

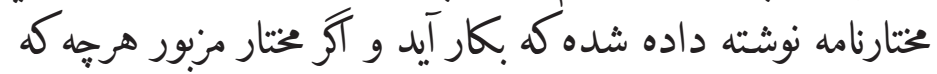

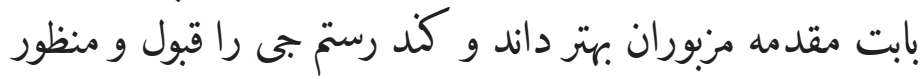

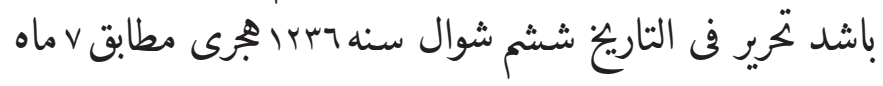
جلاى سنه ابrA عيسوى بيضه

१ સા રૂસ્તમ નૌસેરવાનજી શહી દશતૂર [7] જી

[Right margin]

૧ રતનજી ફોરમજી શાખ

૧ અઘેઆરૂ દારાબજી નવરોજજી શાખ

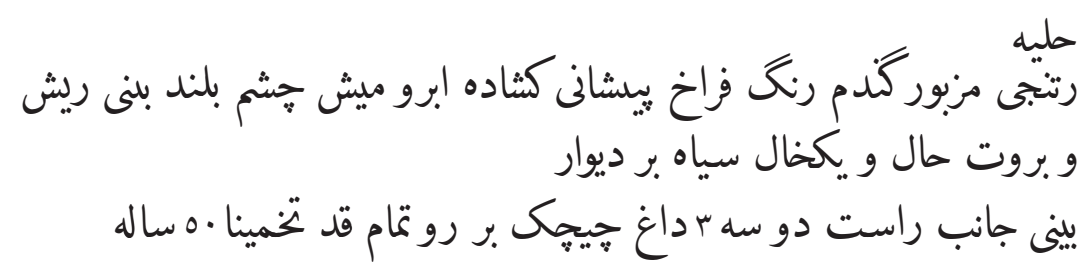
حليه 


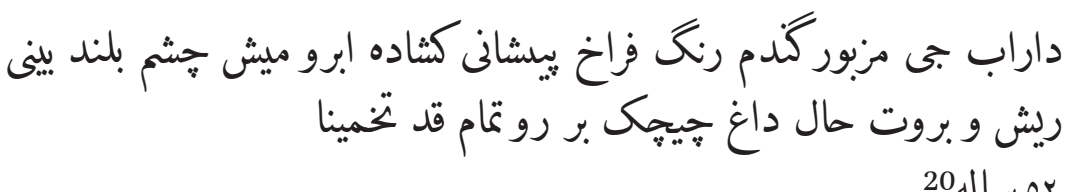

\section{Translation:}

Invocation: [on top left] Kanpani [Company] Bahädur [on top right] seal of the mufti of the city, Nizamuddin with an Arabic text meaning 'in the presence of two witnesses mentioned in the text'.

The main text:

The purpose of this document is that we, Ratanji son of Hormazjialias kotwal and Darabji son of Nauroji, [who] are the residents of mohalla Rustampura, Surat, city of the blessed port, declare that in our presence, Rustamji son of Nausherwanji Dastoor gave an absolute authority (mukhtār-i kul) to Karorji son of Bahramji to litigate, counterlitigate, and question and answer in the honourable court in the cases involving Narainji and Surji and others, heirs of Pragji son of Rudrji, and the second (case) involving Ratanji son of Khurshedji and others, [total] 10 cases, and made him his confidant on the condition that if the abovementioned attorney (mukhtār) could respond to questions, he may do so, otherwise appoint someone else as his representative (wakil), and collect money [ from the respondants] in accordance with the court's written order and issue written receipt to the superintendent (näzir) of the court and if he has to submit a report, he will do so, in addition, he will collect money from people in whose cases a court's order has been previously issued and also give receipts, he has the authority to do all these, and I, Karorji, the aforesaid attorney, accept the aforesaid power of attorney from abovementioned Rustamji, therefore, these few lines have been written as a power of attorney (mukhtār-nāma), to be of use, and if the aforesaid attorney does whatever he deems appropriate with regard to abovementioned cases this will be acceptable and agreeable to Rustamji; written on 6 Shawwal 1236 Anno Hijri which is 7 July 1821 in the Christian calendar.

On the margins:

Bottom of the page: (in Gujarati): Sā Rustam Nausherwanji śahī daśtūr [7] jī Right margin (in Gujarati): Ratanjī Horamjī śākh; external appearance [in Persian]: aforesaid Ratanji, brown colour, broad forehead, wide eyebrows, grey eyes, elevated nose, beard and moustache, a black mole on the right side of the

20 DML, Navsari, Gujarat, India, U 45, part IV, doc. no. 238. A hand copy of this document is also included in this collection (U 45, part IV, doc. no. 243). 
septum of the nose, two-three marks of smallpox on the face, average height, [age 50 years

Right margin (in Gujarati): Adheāru Darabji Nauroji sākh; external appearance [in Persian]: aforesaid Darabji, brown colour, broad forehead, wide eyebrows, grey eyes, elevated nose, beard and moustache, marks of smallpox on the face; average height, $[$ age $] 5^{2}$ years.

In early modern and colonial India, trade, especially long-distance maritime trade, was a complex enterprise in which merchants, ship-owners, bankers, brokers, and agents were bound together in a complementary as well as competitive relationship. Monetary transactions (borrowing/debt and lending/credit) played a vital role in the economy. Indeed, the entire commercial system was based on transactions involving credit and debt. There was a wellestablished mechanism to facilitate this transaction. Bills of exchange (hundi or promissory notes), borrowing cash from a banker (sāhükär) or a merchant, advance buying (advancing money to producers and artisans for a future delivery of goods), and selling against a future payment were various forms of credit-based transaction..$^{21}$ To carry out long-distance trade, where extensive capital was required and where risks were high, merchants pooled together their resources and formed partnerships with members of their family, community, and merchants of other communities. ${ }^{22}$ Trust was the bedrock of all transactional relationships in the society. Merchants trusted their business

21 There is a good literature on these aspects of the Indian economy. I. Habib, "Banking in Mughal India." In Contributions to Indian Economic History, ed. T. Raychaudhuri, vol. 1 (Calcutta: 1960): 1-20; I. Habib, "The System of Bills of Exchange (Hundis) in the Mughal Empire." Proceedings of the Indian History Congress 33 (1971): 290-303; Chaudhuri, Trade and Civilisation in the Indian Ocean: 210-12; O. Prakash, Bullion of Goods: European and Indian Merchants in the Indian Ocean Trade, 1500-1800 (Delhi: Manohar, 2004): 398-415; O. Prakash, European Commercial Enterprise in Pre-Colonial India (Cambridge: Cambridge University Press, 1998); C. Markovits, The Global of World of Indian Merchants, 1750-1947: Traders of Sind from Bukhara to Panama (Cambridge: Cambridge University Press, 200o): 185-94. For a recent study of the role of credit and debt in Indian Ocean trade in the nineteenth and twentieth centuries, see F.A. Bishara, "Mapping the Indian Ocean World of Gulf Merchants, c. 1870-196o." In The Indian Ocean: Oceanic Connections and the Creation of New Societies, ed. A. Sheriff and E. Ho (London: Hurst \& Company, 2014): 83-5 and Bishara, The Sea of Debt.

22 Habib, "Merchant Communities in Precolonial India": 388-96; Markovits, The Global of World of Indian Merchants: 157-66; G.A. Nadri, Eighteenth-Century Gujarat: The Dynamics of Its Political Economy, 1750-180o (Leiden: Brill, 2009): ch. 3; G.A. Nadri, "Merchant Communities and Cross-Cultural Trade Between Gujarat and the Gulf in the Late 
partners, brokers, and agents with capital and goods anticipating a return on the investment. ${ }^{23}$ They generally valued trust, but it was also at times breached, which then caused commercial disputes. To preserve trust and avoid disputes, merchants had recourse to written agreements and contracts, which were legal documents and could be used in a court of law. ${ }^{24}$ It was the culture of formal and informal legal adjudication which gave stability to the commercial economy of the Indian Ocean world. The fact that the wronged party in any dispute was likely to take the matter to a court of law or to an informal arbitration must have had an impact on merchants and induced them to abide by the terms of contracts.

A common feature of the merchants' professional and legal world was the practice of entrusting another person with the power of attorney who then represented his client in business and legal matters. This was particularly the case when a dispute was litigated in a court of law and the clients were to be represented by persons experienced in legal matters. Merchants, in particular, availed themselves of this service. They issued a mukhtār-nāma to a trustworthy person with some legal expertise and skills to represent his client in commercial disputes in a law court. This enabled them (either plaintiff or defendant) to seek justice and protect their commercial interests without themselves being distracted from their extensive commercial enterprise.

The aforementioned mukhtār-nāma issued by Rustamji of Surat to Karorji is an example of interpersonal collaboration and trust whereby the former entrusted the latter as his representative and authorised him to carry out business transactions on his behalf. The document does not specify this, but the fact that Rustamji was transacting business with multiple clients and was in a legal dispute with many of them suggests that he was a merchant and had commercial/financial dealings with other Parsi and Bania merchants and inhabitants of Surat. Rustamji appointed Karorji as his plenipotentiary (mukhtār-i kul) with full authority to represent him in the litigations against his respondents. This mukhtār-nāma falls into the category of particular contracts. ${ }^{25}$ The prin-

Seventeenth and Eighteenth Centuries." In The Gulf in World History: Arabia at the Global Crossroads, ed. A.J. Fromherz (Edinburgh: Edinburgh University Press, 2018): 91-104.

23 For a discussion of the role of trust among Shikarpuri merchants of Sind, see Markovits, The Global of World of Indian Merchants: 260-5.

24 Extant documents indicate that many transactions were formalised in a written contract and signed by the concerned parties and witnesses and, in some cases, were also ratified by a judicial officer. Even minor transactions, such as agrarian taqaw̄̄ loans (not exceeding a few rupees) in villages and small towns, such as Navsari, were recorded for future reference. DML, U 45, part I, doc. no. 49 .

25 An example of a general contract is the deed of representation issued by Anwaruddin Khan Bahadur, governor of Arcot and Karnatak, in 1778 appointing Stephen Sullivan as his 
cipal, Rustamji, authorised the agent, Karorji, to represent him in specific court cases against members of the Pragji and Khurshedji families and entrusted him specifically to collect the outstanding money, as per the court's decision, from the aforesaid respondents. How this collection was to be carried out was left entirely to the agent, Karorji, and his best judgement.

The primary purpose of documenting commercial transactions was to use the document as a reference or a reminder to both parties of their responsibilities and expectations and, more importantly and as is also generally stated in the documents, as a proof or evidence if a dispute arose between the concerned parties ('ind al-hājat hujjat bāshad or bikär āyad). ${ }^{26}$ The principal or the stakeholder, therefore, sought to ensure the authenticity of the document by making the concerned parties and a few witnesses sign the document. The scribes carefully drafted the text making sure that the language was precise and as clear as possible. In this particular document, the scribe has listed the tasks the agent was expected to carry out and also made clear that the agent was to do his job according to his best judgement and appoint another person as his agent ( $w a k i \bar{l}$ ) to prosecute the cases if he so wished. The identification of the concerned parties and witnesses is important and, in the mukhtār-nāma presented here, the principal, agent, and respondents are identified with their fathers and witnesses with their fathers and residential addresses. ${ }^{27}$ Interestingly, neither the principal nor the agent provides any personal details except the names of their fathers. To ensure authenticity, the principal and the two witnesses sign the document in Gujarati and the physical appearances of the two witnesses and their approximate age are given on the margins in Persian. The document was attested by the mufti of Surat, Nizamuddin, in the presence of the witnesses, and his seal is affixed on top of the document, which further authenticated the document for legal purposes. Being an advisor to the qazi and a member of the court, his attestation must have rendered

agent (wakīl) in London. Sullivan's responsibilities as an agent in London are not specified in the document and he was to serve in that capacity as long as he was deemed fit for the job. Bodleian Libraries, Oxford, Mss. Eng. Hist. c. 471: ff. 85a-b. This document is bilingual, the main deed being in Persian with the signature and seal of the governor, while an English translation is provided on the right half of the page. There are no witnesses, nor does the document bear the signature of the agent. Unlike the mukhtār-nāma under discussion in the present article, this deed of representation is not ratified by a mufti or a qazi.

27 Witnesses, Ratanji and Darabji, declare in the document that they are residents of 'Mohalla Rustampura in Surat, the city of the blessed port'. DML, U 45, part IV, doc. nos. 238,243 . 
it an invaluable document to be used as evidence in the East India Company's court in Surat or Bombay.

In the socio-cultural milieu of Surat, a merchant's trustworthiness and how well his peers thought and spoke about him constituted his social capital, which was a vital factor in shaping commercial relationships like agency and partnership. In early modern and colonial India, merchants formed business partnerships and collaborated in commercial ventures. Such relationships were commonly formed with members of the same community as well as with those of other communities based on interpersonal connections and trustworthiness. This clearly transpires from the mukhtār-nāma under discussion here, in which we see a Parsi merchant authorising another Parsi to transact business on his behalf, and the two witnesses also being drawn from the same community. ${ }^{28}$ The inference one can draw from this about the Parsi community identity matches the impression we get from the literature of the Parsis having a strong sense of community identity and a concern for the community because of their distinct religious and social culture as well as their minority status in western India. ${ }^{29}$

The mukhtār-nāma under discussion in this paper, like many other similar documents in local languages available in the archives and personal collections, serves as a window through which one can look into the complex world of Indian merchants and other economic actors in early modern and colonial western India. ${ }^{30}$ It transpires from this document that there were commercial disputes between Rustamji and his defendants, Narainji, Surji, Ratanji,

28 DML, U 45, part IV, doc. nos. 238, 243. In a petition, written in May 1722, demanding recovery of merchandise that Abdul Karim Baghdadi had lost in Surat, the signatories were all Arab Muslim merchants. This shows the reputation of Abdul Karim among his peers and the professional solidarity among Arab merchants of Baghdad, Basra, and other places trading with Surat. DML, U 45, part. I, doc. no. 9 .

29 Parsi identity has attracted a good deal of scholarly attention and some recent studies have shown that while they freely cooperated and collaborated with other communities, they "remained ever conscious of the need to safeguard and distinguish their minority community identity." J.S. Palsetia, The Parsis of India: Preservation of Identity in Bombay City (Leiden: Brill, 2001): 19. A power of attorney issued by Hossamji Pestonji Parsi to Perojshah Ratanji Baria Parsi of Surat in 1932 giving the latter a wide range of authority to represent him in court cases, carry out financial and commercial transactions on his behalf, and take care of his properties, is indicative of trust and partnerships among members of the same community. An attested copy of a power of attorney issued by Hossamji Pestonji in the Indore Residency on 23 December 1932. Author's personal collection.

The mukhtār-nāma and other documents in the collection of Persian documents at the First Dastoor Mehrjirana Library, such as a merchant's petitions for recovery of his merchandise, a mortgage contract ( $r a h n)$, and a taqūwi loan document among others, represent different types of commercial and legal transactions. DML, U 45, part I, doc. 
and others. The defendants, it seems, had borrowed money from Rustamji or taken merchandise on credit or received an advance payment for merchandise they undertook to supply to Rustamji, but did not pay or declined to pay off the debt or failed to deliver the merchandise. Misunderstanding or disagreement over distribution of sale proceeds and profits in a joint venture may also have caused a dispute and the litigation. Whatever the cause, Rustamji took the matter to court anticipating that he would get his money back through the court's rulings in his favour. ${ }^{31}$ There were ten pending cases in the court in which the agent had to represent the principal, Rustamji, and collect the money the defendants owed. Presumably, Rustamji kept records of commercial transactions with the defendants, which his agent may have used in the court. Rustamji's case typifies the complex world of merchants in which they were connected with each other through networks of exchange of money, merchandise, and service. As we noted at the beginning of this analysis, credit underpinned almost all commercial transactions in the Indian Ocean world. While in general the system worked fairly well, there were some who defaulted and caused commercial disputes, which was then litigated in a court of law. In the seventeenth and eighteenth centuries, people of all faith could take their civil and criminal cases to the local courts of the qazi or seek arbitration by a mutually nominated group of leading merchants and local elites. ${ }^{32}$ In the late eighteenth and early nineteenth centuries in western India, local merchants, especially the Parsis, Banias, and Armenians, increasingly litigated their cases in the East India Company's colonial court of law because of its legal pluralism and incorporation of local customary laws and practices in the dispensation of justice and also because other forums were gradually disappearing and were no longer available for them. ${ }^{33}$

nos. 9, 37, and 49. Transactions like these characterised the "bazaar economy" of western India, which was an integral part of the Indian Ocean world economy.

31 DML, U 45, part IV, doc. nos. 238, 243.

32 In the civil cases involving non-Muslims, a Brahmin/Hindu scholar (Pandit) advised the qazi and gave his legal opinion on the case. Ahmad, The Administration of Justice in Medieval India: 115. For more details and examples of Hindu Banias of Gujarat litigating their cases at the qazi's court, see A. Shafqat, "Judicial Administration in Mughal Gujarat." Proceedings of the Indian History Congress 71 (2010-2011): 417-26; G.A. Nadri, "The Maritime Merchants of Surat: A Long-Term Perspective." Journal of the Economic and Social History of the Orient 5o/2-3 (2007): 245 .

33 G.D.S. Sood, "Sovereign Justice in Precolonial Maritime Asia: The Case of the Mayor's Court of Bombay, 1726-1798." Itinerario 37/2 (2013): 46-72; L. Hodges, "Between Litigation and Arbitration: Administering Legal Pluralism in Eighteenth-Century Bombay." Itinerario 42/2 (2018): 490-515. 
Most documented transactions were basically agreements or declarations (iqrār-nämas or qarār-nāmas) between the concerned parties, which were generally recorded in the presence of witnesses. In the case of dispute and litigation, these documents were used as evidence in support or denial of a claim. It was the plaintiff's or defendant's responsibility to convince the judge or the jury of the court that the documents submitted in support of the claim were true and verifiable. In recording a commercial transaction where stakes were high, the principal merchant or the stakeholder did his best to ensure that it was recorded in an unambiguous language and even sought appropriate witnesses to validate the transaction. Sometimes, they obtained the signature or seal of the local officials, such as the qazi or mufti, to authenticate the document. This was particularly the case with documents which were specifically prepared for the courts. ${ }^{34}$ The mukhtār-nāma under discussion here is ratified by the mufti of the city. Rustamji possibly kept the original with him and a handwritten copy was submitted to the court. ${ }^{35}$ Once the court was apprised of this arrangement, the agent was entitled to follow up with the cases to secure the court's rulings in favour of his client.

The courts under the East India Company's government in India and elsewhere in the western Indian Ocean accepted all kinds of documents in Persian and other indigenous languages (with a translation in English) as evidence, and upon verifying their authenticity resolved the disputes and gave their rulings. The court in Surat received a copy of the mukhtār-nāma presently under discussion and entered it on page 22 of the register on 26 July $1821 .{ }^{36}$ The agent, Karorji, may have received from his client and submitted to the court documentary evidence of all disputed transactions to convince the court of the legitimacy of his client's claims. Gagan Sood has rightly noted that "the grant of a power of attorney on its own was seldom enough for the principal's orders to be executed without a hitch. It was invariably reinforced and supplemented by other mechanisms, especially other kinds of documentation."37 When necessary, merchants were able to use any recorded commercial transaction as a

34 A deed of representation issued in 1732 by the governor of Arcot and Carnatic, authorizing Stephen Sullivan as his wakil in London, was not attested by any witnesses. Bodleian Libraries, Oxford, Mss. Eng. hist. c. 471: ff. 85a-b. A power of attorney (wikāla-nāma) issued by Shah Kawthar, a representative of a Sufi brotherhood in Najaf, to Sayyid Isa, probably a merchant, was attested by a witness. Sood, India and the Islamic Heartlands: 224-5.

35 DML, U 45, part IV, doc. no. 243.

36 DML, U 45, part IV, doc. no. 243 .

37 Sood, India and the Islamic Heartlands: 225. 
piece of evidence valid in the court of law and obtain a ruling in their favour and the defendants questioned and contested the veracity of the evidence and presented their evidence in support of their claims. ${ }^{38}$ Records of commercial transaction between merchants were legal documents and were accepted as evidence if a dispute arose and it was litigated in a court of law. The documents in indigenous languages were central to the justice system of the precolonial Mughal courts headed by a qazi as well as of the colonial courts of the East India Company.

\section{Conclusion}

The mukhtār-nāma that we have presented and discussed here is one of the last of such documents of non-doctrinal/religious nature bearing a mufti's seal and authentication. As the nineteenth century progressed, the colonial state took this power of authentication away from the office of the qazi and the mufti, thereby confining the legal authority of these Mughal offices to Islamic "doctrinal" matters alone. This was part of the larger colonial endeavour to redefine the Islamic law and its legal domain in India. In the nineteenth century, the East India Company appropriated the right to authenticate "secular" contracts. This right had, until then, been exercised by the notarial office of the qazi and the mufti. ${ }^{39}$ This transition is reflected very well in this document, which begins with an invocation to the authority of the East India Company. The term Kanpani [Company] Bahädur (Honourable Company) is inscribed on top of the page. ${ }^{40}$ Since the document was also authenticated by the mufti of the city, it may be argued that some local precolonial legal practices continued in the colonial period. Although the colonial state successfully claimed its authority over the non-religious legal matters and some changes were made in

38 This is best illustrated by a power of attorney issued by a group of Armenians in Isfahan to fellow Armenians residing in Amsterdam or Venice in $175^{\circ}$ soliciting their assistance and asking them to send an Armenian to London to enter a legal claim for the cargo of the ship, Santa Catharina, on behalf of the owners in the High Court of Admiralty. The document, which was not addressed to any Armenian by name and whose authenticity the defendants questioned, was accepted in the court and the Court of Directors of the East India Company was convinced of its genuineness and assisted the Armenian in his pursuit of justice. S. Aslanian, "Trade Diasporas versus Colonial State: Armenian Merchants, the English East India Company, and the High Court of Admiralty in London, 1748-1752." Diaspora: A Journal of Transnational Studies 13/1 (2004): 67-73.

39 Lhost, "Writing Law at the Edge of Empire": 264.

40 DML, U 45, Part IV, doc. no. 238. 
the legal notarial procedures, older forms and structures of legal documentation as well as vocabulary continued in the nineteenth century. ${ }^{41}$

Our analysis of this mukhtār-nāma shows that a document-centred study reveals a lot more about peoples' lives, their everyday realities and challenges, and above all the socio-cultural milieu, in which culture, commerce, and state intersected, overlapped, and influenced each other than what the conventional scholarship has explored so far. Such an approach helps us debunk the assumption that commercial transactions between local merchants and other economic actors in early modern India were not written down. Such documents in Persian (as in Arabic and other non-European languages) from the early seventeenth century onward, which are now accessible to scholars either as originals or copies, suggest that there was a strong tradition of documenting commercial transactions in the Indian Ocean world. ${ }^{42}$ Moreover, doing commercial history of early modern and colonial India through documents prepared and used for legal purposes reveals a lot about the social-cultural milieu in which such transactions took place, as well as the dynamics of the judicial culture in the region and the legal institutional framework, which enabled them to take commercial opportunities, transact business, and negotiate their differences and disputes. The mukhtār-nāma under study and other similar such documents also reflect on local merchants' and communities' responses to and engagement with the evolving colonial law and the judicial system. In these documents of the early colonial period, one may trace the beginning of the Parsi proclivity to benefit from the East India Company's judicial system before pivoting to inserting themselves in the system and manipulating it during the late colonial period, as a recent study by Mitra Sharafi has illustrated so well. ${ }^{43}$

41 See for example, H.H. Wilson, A Glossary of Judicial and Revenue Terms, and of Useful Words Occurring in Official Documents Relating to the Administration of the Government of British India (London: William H. Allen and Co., 1855).

42 Collection of Persian documents (copies) from the Mughal period in the Bibliothique Nationale, Paris (Surat documents, Blochet Supplementary Pers, 482) and in Geleynssen de Jongh collection (Emperor Jahangir's farmäns with a Dutch translation) in the National Archives, the Hague, Netherlands, and documents from Allahabad and Gujarat in the Uttar Pradesh State Archives and the National Archives of India contain useful information on taxation, merchants, trade, shipping and navigation, and commercial practices and institutions.

43 M. Sharafi, Law and Identity in Colonial South Asia: Parsi Legal Culture, 1772-1947 (Cambridge: Cambridge University Press, 2014). 


\section{Acknowledgements}

I would like to thank the reviewers of this paper for their valuable comments and suggestions. I am particularly thankful to Nandini Chatterjee, Samira Sheikh, Daniel Sheffield, and Saeed Nadjariun for their help in transliterating the Persian and Gujarati texts of the document. I thank the European Research Commission and the Lawforms project for providing funds to publish this article, and the entire issue, in Open Access format.

\section{Bibliography}

\section{Abbreviations \\ DML First Dastoor Meherjirana Library}

\section{Unpublished Sources}

Correspondence and Papers of Laurence Sulivan, Oxford, Bodleian Libraries Mss. Eng. hist. c. 471.

Miscellaneous documents, DML, Navsari, Gujarat, U 45, part IV.

\section{Published Sources}

Abdullah, Thabit A.J. 2001. Merchants, Mamluks, and Murder: The Political Economy of Trade in Eighteenth-Century Basra. New York: sunY Press.

Ahmad, Mohammad Basheer. 1941. The Administration of Justice in Medieval India: a Study in Outline of the Judicial System under the Sultans and the Badshahs of Delhi Based mainly upon Cases Decided by Medieval Courts in India between 1206-1750 A.D. Allahabad: The Allahabad Law Journal Press.

Alam, Muzaffar and Sanjay Subrahmanyam. 2010. Witnesses and Agents of Empire: Eighteenth-Century Historiography and the World of the Mughal Munshi. Journal of the Economic and Social History of the Orient 53/1-2: 393-423.

Aslanian, Sebouh. 2004. Trade Diasporas versus Colonial State: Armenian Merchants, the English East India Company, and the High Court of Admiralty in London, 17481752. Diaspora: A Journal of Transnational Studies 13: 67-73.

Aziz, Muhammad Ridhwan Ab. 2016. Islamic Commercial Law (Fiqh Muamalat): Theory and Application of Selected Contracts. Malaysia: Universiti Sains Islam Malaysia.

Bishara, Fahad Ahmad. 2017. A Sea of Debt: Law and Economic Life in the Western Indian Ocean, 1780-1950. Cambridge: Cambridge University Press.

Bishara, Fahad Ahmad. 2014. Mapping the Indian Ocean World of Gulf Merchants, c. 1870-196o. In The Indian Ocean: Oceanic Connections and the Creation of New Societies, ed. Abdul Sheriff and Engseng Ho. London: Hurst \& Company. 
Chatterjee, Kumkum. 2010. Scribal Elites in Sultanate and Mughal Bengal. The Indian Economic and Social History Review 47/2: 445-72.

Chaudhuri, K.N. 1985. Trade and Civilisation in the Indian Ocean: An Economic History from the Rise of Islam to 1750. Cambridge: Cambridge University Press.

Chaudhuri, K.N. 1991. Reflections on the Organizing Principles of Premodern Trade. In The Political Economy of Merchant Empires: State Power and World Trade, 1350-1750, ed. J.D. Tracy. Cambridge: Cambridge University Press: 421-42.

Elliot, H.M. and J. Dowson, ed. 1867-77. History of India as Told by Its Own Historians: the Muhammadan Period. 8 vols. London.

The Encyclopaedia of Islam, New Edition. 2002. Vol. 11. Leiden: Brill.

Gupta, Ashin Das. 2001. Some Problems of Reconstructing the History of India's West Coast from European Sources. In The World of the Indian Ocean Merchant, 1500-1800: Collected Essays of Ashin Das Gupta, comp. by Uma Das Gupta. New Delhi: Oxford University Press.

Gupta, S.P. 1986. The Agrarian System of Eastern Rajasthan, c. 1650-1750. Delhi: Manohar. Habib, Irfan. 196o. Banking in Mughal India. In Contributions to Indian Economic History, ed. Tapan Raychaudhari. Vol. 1. Calcutta: 1-20.

Habib, Irfan. 1971. The System of Bills of Exchange (Hundis) in the Mughal Empire. Proceedings of the Indian History Congress 33: 290-303.

Habib, Irfan. 1990. Merchant Communities in Precolonial India. In The Rise of Merchant Empires: Long-Distance Trade in the Early Modern World, 1350-1750, ed. J.D. Tracy. Cambridge: Cambridge University Press: 371-99.

Habib, Irfan. 1999. The Agrarian System of Mughal India, 1556-1707. New Delhi: Cambridge University Press.

Habib, Irfan. 2005-2006. Persian Book Writing and Book Use in the Pre-Printing Age. Proceedings of the Indian History Congress 66: 514-37.

Hasan, Farhat. 2002. Towards a Theory of Social Communication in Pre-Colonial India. Proceedings of the Indian History Congress 63: 396-412.

Hodges, Leonard. 2018. Between Litigation and Arbitration: Administering Legal Pluralism in Eighteenth-Century Bombay. Itinerario: Journal of Imperial and Global History 42/3: 490-515.

Kinra, Rajeev. 2010. Master and Munshi: A Brahman Secretary's Guide to Mughal Governance. The Indian Economic and Social History Review 47/2: 527-61.

Lhost, Elizabeth. 2018. Writing Law at the Edge of Empire: Evidence from the Qazis of Bharuch (1799-1864). Itinerario:Journal of Imperial and Global History 42/2: 256-78.

Markovits, Claude. 2000. The Global of World of Indian Merchants, 1750-1947: Traders of Sind from Bukhara to Panama. Cambridge: Cambridge University Press.

Nadri, Ghulam A. 2007. The Maritime Merchants of Surat: A Long-Term Perspective. Journal of the Economic and Social History of the Orient 50/2-3: 235-58. 
Nadri, Ghulam A. 2009. Eighteenth-Century Gujarat: The Dynamics of Its Political Economy, 1750-1800. Leiden: Brill, 2009.

Nadri, Ghulam A. 2018. Merchant Communities and Cross-Cultural Trade Between Gujarat and the Gulf in the Late Seventeenth and Eighteenth Centuries. In The Gulf in World History: Arabia at the Global Crossroads, ed. Allen James Fromherz. Edinburgh: Edinburgh University Press: 91-104.

Palsetia, Jesse S. 2001. The Parsis of India: Preservation of Identity in Bombay City. Leiden: Brill.

Pollock, Sheldon, ed. 2011. Forms of Knowledge in Early Modern Asia: Explorations in the Intellectual History of India and Tibet, 1500-1800. Delhi: Manohar.

Prakash, Om. 1998. European Commercial Enterprise in Pre-Colonial India. Cambridge: Cambridge University Press.

Prakash, Om. 2004. Bullion of Goods: European and Indian Merchants in the Indian Ocean Trade, 1500-180o. Delhi: Manohar.

Saleem, Muhammad Yusuf. 2013. Islamic Commercial Law. Singapore: John Wiley \& Sons.

Shafqat, Arshia. 2010-11. Judicial Administration in Mughal Gujarat. Proceedings of the Indian History Congress 71: 417-26.

Sharafi, Mitra. 2014. Law and Identity in Colonial South Asia: Parsi Legal Culture, 17721947. Cambridge: Cambridge University Press.

Sood, Gagan D.S. 2013. Sovereign Justice in Precolonial Maritime Asia: The Case of the Mayor's Court of Bombay, 1726-1798. Itinerario: Journal of Imperial and Global History 37/2: 46-72.

Sood, Gagan D.S. 2016. India and the Islamic Heartlands: An Eighteenth-Century World of Circulation and Exchange. Cambridge: Cambridge University Press.

Udovitch, Abraham L. 1970. Partnership and Profit in Medieval Islam. Princeton, NJ: Princeton University Press.

Wilson, H.H. 1855. A Glossary of Judicial and Revenue Terms, and of Useful Words Occurring in Official Documents Relating to the Administration of the Government of British India. London: William H. Allen and Co. 